\title{
Erratum to: a subanesthetic dose of ketamine in the Rhesus monkey reduces the occurrence of anticipatory saccades
}

\author{
Ilhame Ameqrane ${ }^{1} \cdot$ Nicolas Wattiez $^{2} \cdot$ Pierre Pouget $^{2} \cdot$ Marcus Missal $^{1}$
}

Published online: 5 August 2015

(C) Springer-Verlag Berlin Heidelberg 2015

Erratum to: Psychopharmacology

\section{DOI 10.1007/s00213-015-4005-Z}

The original version of the above article contained a mistake it the presentation of the author names. The correct presentation is below:

Ilhame Ameqrane

Nicolas Wattiez

Pierre Pouget

Marcus Missal

The online version of the original article can be found at http://dx.doi.org/ 10.1007/s00213-015-4005-z.

Marcus Missal

marcus.missal@uclouvain.be

1 Institute of Neurosciences (IONS), Cognition and System (COSY), Université catholique de Louvain, 53 av Mounier,B1.53. 4 COSY, 1200 Brussels, Belgium

2 ICM, CNRS, INSERM, Université Pierre et Marie Curie, Hôpital de la Salpêtrière, Paris, France 